\title{
The Massachusetts Health Plan: Public Insurance for the Poor, Private Insurance for the Wealthy, Self-Insurance for the Rest?
}

\author{
Timothy Stoltzfus Jost
}

The Massachusetts Law for "Providing Access to Affordable, Quality, Accountable Health Care" represents one of the most ambitious attempts yet by one of the United States to reform its health care financing system.' It is useful, however, to situate this reform in the context of a larger discussion of health care financing reform that has been underway for some time.

For at least the past quarter century, three visions of how to reform health care finance in the United States have competed for the allegiance of policy makers. The first of these visions calls for expansion of public insurance to achieve universal coverage, or something very close to it. ${ }^{2}$ This model is often characterized as a single-payer model, although universal public coverage does not, of course, require a single payer. Many of the world's social insurance programs in fact have multiple payers. ${ }^{3}$ One way to achieve universal coverage through public insurance would be to expand the Medicare program to cover the entire population. ${ }^{4}$ Universal coverage, however, could also be achieved

- Robert L. Willett Family Professor, Washington and Lee University School of Law. This article is based in part on the author's book. TIMOTHY STOLTZFus Jost, Health CARE AT RISK: A CRITIQUE OF THE CONSUMER-DRIVEN MOVEMENT (forthcoming 2007).

1. H.B. 4479, 2006 Leg., 2d Ann. Sess. (Mass. 2006 (enacted)).

2. Physicians for a National Health Program Home Page, http://www.pnhp.org.

3. See DAVID CHINITZ et al., Governance and (Self-) Regulation in Social Health Insurance Systems, in SOCIAL HEALTH INSURANCE SYSTEMS IN WESTERN EUROPE 155, 155 (Richard B. Saltman, Reinhard Busse \& Josep Figueras eds., 2004) (pointing out that some social insurance systems use multiple social insurance funds); Elias MOSSIALOS \& ANNA DiXON, Funding Health Care: An Introduction, in FUNdING HEALTH CARE: OPTIONS FOR EUROPE 1, 17 (Elias Mossialos et al. eds., 2002) (same); Timothy Stoltzfus Jost, Why Can't We Do What They Do? National Health Reform Abroad, 32 J. L. MED. \& ETHICS 433, 433-39 (2004) (describing various models used by other countries for financing health care).

4. See The Writing Committee for the Physicians' Working Group for Single-Payer National Health Insurance, Proposal of the Physicians' Working Group for Single-Payer National Health Insurance, 290 J. AM. MED. ASS'N 798, 798 (2003) (noting that a fundamental change in U.S. health care could build upon traditional Medicare), available at http://www.pnhp.org/publications/ proposal_of_the_physicians_working_group_for_singlepayer_national_health_insurance.php. 
through expansion of Medicaid or through the creation of an entirely new program.

Universal access can readily be achieved through this approach-this is how the rest of the world does it. There is, moreover, overwhelming evidence that costs can be controlled in public insurance systems through budgets, administered prices, negotiations, or some combination of the three. ${ }^{5}$ Although public programs have in fact continued to expand in the United States in recent years, the political barriers that face a universal public program seem simply insurmountable.

The other two visions of reform are market based. The first of these is the model of managed competition. This model, based on the work of Alain Enthoven and the Jackson Hole Group, attempts to organize the insurance market to encourage competition among insurers to bring down health care costs. ${ }^{6}$ It formed the basis of the Clinton Health Care Plan, and has also provided the conceptual foundation for the Medicare+Choice, Medicare Advantage, and Medicare Part D prescription drug program, as well as the Federal Employees Health Benefits Plan. ${ }^{8}$ This model focuses on controlling health care costs through competition among health plans. Managed competition models are often supplemented, however, with proposals for tax credits or other subsidies for the purchase of insurance to make health insurance more affordable. $^{9}$

The third model, also market-based, is the consumer-driven model. This model advocates market competition at the point of service purchase. Consumers of health care products and services should treat health care just like other products and services, deciding at the point of purchase whether to spend money on it or on something else. ${ }^{10}$

5. See Joseph White, Competing Solutions: american Health Care Proposals and INTERNATIONAL EXPERIENCE 271 (The Brookings Institution 1995) ; Gerard F. Anderson, et al., It's the Prices, Stupid: Why the United States is So Different from Other Countries, HEALTH AFF., MayJune 2003, at 89,103 ("U.S. policymakers need to reflect on what Americans are getting for their greater health spending. They could conclude: It's the prices, stupid.").

6. alain C. Enthoven, health Plan: The Only Practical Solution to the Soaring Cost of Medical Care, at xxi (Addison-Wesley Publication Company 1980); Alain C. Enthoven, The History and Principles of Managed Competition, HEALTH AfF., Supp. 1993, at 24, 24.

7. See Theda Skocpol, The Rise and Resounding Demise of the Clinton Plan, HEALTh AfF., Spring 1995, at 66, 69 (noting that "Clinton rejected the single-payer approach" in favor of a more moderate approach involving purchasing agencies and tax subsidies).

8. See National Center for Policy Analysis, A Primer on Managed Competition: What is Managed Competition?, http://www.ncpa.org/studies/s183/s183d.html (last visited Feb. 28, 2007) (discussing managed competition and its prototypes).

9. ENTHOVEN, HEALTH PLAN, supra note 6, at 121-24.

10. See John C. Goodman \& Gerald L. Musgrave, Patient Power: The free ENTERPRise Alternative to Clinton's HEALTH PlAN, 18-27 (1994) ("In a normal market 
Consumers are also encouraged to shop around to find the lowest price, highest quality health care. This is done by moving consumers to high deductible health plans that leave them with considerable "skin in the game." Consumer-Driven Health Care (CDHC) advocates argue that too much of current health care coverage is not true insurance, but rather wasteful prepayment for health care services that should rather be paid for out of pocket. 12 This "overinsurance" creates moral hazard, causing health care consumers to obtain services and products that they do not really value, and that they would forego if they had to pay for them out of pocket. ${ }^{13} \mathrm{CDHC}$ advocates contend that high deductible policies, which force consumers to pay for most health care products and services out of pocket, will both make consumers more cost conscious and save administrative costs. ${ }^{14}$ Their claim is empirically based as well as ideological-there is ample evidence from the RAND Health Insurance Experiment to the present that increased cost-sharing does lead to decreased use of health care services and that you can save money by making people pay for health care directly. ${ }^{15}$

CDHC advocates generally, although not always, support tax subsidies for health savings accounts (HSA) as a way of making high deductible policies more palatable while still retaining costconsciousness. $^{16}$ They also call for more and better information to help consumers evaluate health care products and services. ${ }^{17}$ The consumerdriven strategy is, like managed competition, primarily a cost-control strategy, although its advocates argue that it will also improve quality and make health care more affordable. ${ }^{18}$

problems are solved by individual initiative on the part of consumers and producers pursuing their own self-interest.").

11. Press Briefing by $\mathrm{Al}$ Hubbard on the President's Health Care Initiatives for 2006, http://www.whitehouse.gov/news/releases/2006/02/20060201-1.html (last visited Feb. 3, 2007).

12. See John C. Goodman \& Gerald L. Musgrave, Patient Power: Solving America's Health Care CRISIS, 3-17, 25-26 (1992) (discussing problems with the American health care system and the role of insurance).

13. See Michael F. Cannon \& Michael D. Tanner, Healthy Competition, 46-53 (2005) (stating that "excessive coverage encourages patients to utilize care without regard to its cost").

14. See GOODMAN \& MUSGRAVE, supra note 12 at 249-53 (advocating use of Medical Savings Accounts).

15. See Michael a. Morrisey, Price Sensitivity in Health Care: Implications for HEALTH CARE POLICY 11-27 (2d ed. 2005) (reviewing empirical literature on the price sensitivity of health services); JOSEPH P. NEWHOUSE \& THE INSURANCE EXPERIMENT, FREE FOR ALL? LESSONS FROM THE RAND HEALTH INSURANCE EXPERIMENT 8-28, 338-71 (1993) (describing the RAND Health Insurance Experiment and its findings).

16. See, e.g., GoOdMAN \& MUSGRAVE, supra note 12, at 231-61 (exploring the potential benefits of high-deductible health insurance and health savings accounts).

17. E.g., id. at $32-35$

18. See, e.g., id. at 249-57 (proposing numerous advantages of health savings accounts). 
The Massachusetts plan does not align itself with any one of these visions of health care reform. It expands public coverage. It includes public coverage through the MassHealth program for low-income persons who fit within the categories of the "worthy poor" traditionally covered by Medicaid --the elderly, disabled, families with children, and pregnant women. ${ }^{19}$ It specifically expands coverage of children through MassHealth. ${ }^{20}$ It also offers a form of managed competition through the newly created Connector, which at least provides a regulated and organized insurance market. ${ }^{21}$ Although the rhetoric of managed competition is not prominent in the plan, the plan does evidence the hope that an organized insurance market will make health insurance more affordable and bring down health care costs. Finally, the Massachusetts plan offers access to subsidized private coverage for persons with incomes up to $300 \%$ of the poverty level in the Commonwealth Care program, which includes elements of both public coverage and managed competition. $^{22}$

The consumer-driven, high-cost-sharing model does not at first glance seem to be featured prominently in the Massachusetts plan. Indeed, the Commonwealth Care plan for residents with incomes below $300 \%$ of the poverty level prohibits deductibles and limits coinsurance, ${ }^{23}$ while deductibles offered through the Connector to higher-income persons are limited to the amount of permissible tax deductible contributions to HSAs under the federal HSA law-currently $\$ 2,650$ for single individuals and $\$ 5,250$ for families. ${ }^{24}$

While the consumer-driven, cost-sharing-based approach is not showcased as an ideological foundation of the Massachusetts plan, it may ultimately be the key to the plan's individual mandate. Although the Massachusetts plan has been promoted as an approach to providing nearly universal insurance, for many middle-income workers that insurance will in fact be largely self-insurance.

The individual mandate is only enforceable under the Massachusetts statute if insurance is "affordable" for individuals. ${ }^{25}$ As John Holahan

19. John E. McDonough et al., The Third Wave of Massachusetts Health Care Access Reform, 2006 HeAlTH AFF.: WeB Exclusive, w420, w421-w422 (describing the expansion of the MassHealth program to "previously ineligible populations").

20. Id.

21. See id. at w423-w424 (describing the Commonwealth Health Insurance Connector Authority).

22. See id. at w423 (describing the Commonwealth Care Health Insurance Program).

23. Id. at $\mathrm{w} 423$.

24. H.B. 4479, 2006 Leg., 2d Ann. Sess. $\S 60$ (Mass. 2000) (enacted).

25. Mass. H.B. $4479 \S 12$. 
and Linda Blumberg point out in their recent Health Affairs article, there are two primary strategies available to health plans to become more affordable to those who do not fall below the Commonwealth Care plan eligibility levels. ${ }^{26}$ Plans can either use highly restrictive provider networks, and thus exclude high-cost providers, or they can rely on high cost-sharing. ${ }^{27}$ Neither strategy is popular in Massachusetts, but if national trends are any indicator, high deductible policies will become more common. Indeed, the Massachusetts statute explicitly allows high deductible HMOs, which are prohibited in other states, including New York. ${ }^{28}$ Coverage standards approved by the Connector Board allow deductibles of up to $\$ 2000$ for an individual and $\$ 4000$ for a family, separate drug coverage deductibles of up to $\$ 250$ for an individual and $\$ 500$ for a family, and out-of-pocket maximums as high as $\$ 5000$ for an individual, $\$ 10,000$ for a family. ${ }^{29}$ Affordable health insurance for those who do not qualify for Commonwealth Care or MassHealth is likely to be insurance with high cost-sharing.

Moreover, even some of those whose incomes fall below the Commonwealth Care eligibility levels may face high cost-sharing. Although high deductible plans are not permitted in the Commonwealth Care program, that program is not generally available to persons whose employers finance $25 \%$ of their premiums (33\% for families). ${ }^{30}$ Employers, however, are increasingly turning to high deductible policies to insure their workers. Although estimates vary, about 2.7 million workers nationally are currently enrolled in HSA-qualified high deductible health plans, and many more employers are currently considering offering high deductible plans. ${ }^{31}$ It is likely, therefore, that many Massachusetts residents whose incomes fall below $300 \%$ of the poverty level will find themselves covered by high deductible policies because those are the only policies offered by their employers, even in situations where the employer pays as little as one-quarter to one-third of

26. John Holahan \& Linda Blumberg, Massachusetts Health Care Reform: A Look at the Issues, 2006 HEALTH AFF.: WEB EXCLUSIVES, w432, w439-w440.

27. Id.

28. Timothy Jost \& Mark Hall, The Role of State Regulation in Consumer-Driven Health Care, 31 AM. J.L. \& MED. 395, 405-06 (2005)

29. Bd. of the Commonwealth Health Insurance Connector Authority, Minutes, March 20, 2007, available at http://www.mass.gov/?pageID=hicmodulechunk\&L=1\&L0=Home\&sid=Qhic\&b= terminalcontent\&f=board_meeting_3.20.07\&csid=Qhic

30. Mass. H.B. $4479 \S 45$.

31. KAISER FAMILY FOUNDATION/HEALTH RESOURCES AND EDUCATIONAL TRUST, EMPLOYER HEALTH BENEFITS, ANNUAL SURVEY, 5 (2006), http://www.kff.org/insurance/7527/upload/7527.pdf [hereinafter KAISER FAMILY FOUNDATION]. 
the cost of the policy. ${ }^{32}$ For many residents whose incomes exceed $300 \%$, moreover, coverage by high deductible employment-related plans is also very likely. Indeed, because of ERISA, those covered by selfinsured employment-related plans will be absolutely unprotected by Massachusetts law if their employers choose to offer only high deductible plans. ${ }^{33}$

It is probable that the Massachusetts Health Care Access Reform will result in a three tier system of health care coverage-a paradigm that is in fact likely to become more and more common throughout the United States generally. On the bottom level, those who are poor enough to qualify for Mass Health (and who are categorically eligible for it) will receive comprehensive coverage. Low Medicaid payment rates are likely to restrict their choice of provider, but if they can find providers who participate in Medicaid, the services and products of those providers will be covered in full. ${ }^{34}$ Those in Mass Health will receive coverage with no deductibles and with very limited cost-sharing ( $\$ 3$ per hospital visit, $\$ 1$ to $\$ 3$ per prescription). ${ }^{35}$ Those slightly better off will be eligible for Commonwealth care, with no deductibles and limited copayments. ${ }^{36}$

At the other extreme, in the top tier, will be those who continue to receive conventional employment-related group insurance. Assuming that Massachusetts is like the rest of the nation, this insurance will continue to be provided for most insureds through preferred provider organizations (PPOs) with broad networks and loose controls over utilization. ${ }^{37}$ Cost sharing will probably be higher than it was a decade ago, but will likely be manageable, and will most likely take the form of copayments. ${ }^{38}$ Coverage will be comprehensive, indeed, given the

32. Over half of members of employment-related high deductible health plans have no choice of health plan. PAUl Fronstin \& SARA COLlins, THE 2ND ANNUAL EBRI/COMMONWEALTH FUND CONSUMERISM IN HEALTH CARE SURVEY, 2006: EARLY EXPERIENCE WITH HIGH-DEDUCTIBLE AND CONSUMER-DRIVEN HEALTH PLANS, 14 (2006), http://www.ebri.org/pdf/briefspdf/EBRI_IR_1220061.pdf.

33. Self-insured plans are not subject to state regulation under the preemption provisions of ERISA. 29 U.S.C. $§ 1144$ (2000); see BARRY R. FURROW, HEALTH LAW, 654-59 (5th ed. 2004) (discussing the ERISA Act of 1974).

34. See Steven Zuckerman et al., Changes in Medicaid Physician Fees, 1998-2003: Implications for Physician Participation, 2004 HeAlth Aff.: Web Exclusives, w4-374, w4-374 (documenting low physician participation in Medicaid).

35. Mass. H.B. $4479 \S 45$.

36. Id.

37. See Robert E. Hurley et al., The Puzzling Popularity of the PPO, HEALTH AfF., Mar.-Apr. 2004, at 56 (discussing the advent of PPOS as "the most popular health benefit option among U.S. workers").

38. KAISER FAMILY FOUNDATION, supra note 31, at 3-4. 
extensive coverage and provider mandates found in Massachusetts, it will probably be very comprehensive.

Some of these higher-income insureds may have high deductible policies. Much of the dramatic movement toward high deductible plans in the past couple of years has been among high-income households. ${ }^{39}$ Some of these high-income households are insured through individual (nongroup) policies, while some have employment-based coverage.

High-income persons who choose coverage through high deductible health plans coupled with HSAs enjoy substantial tax benefits-indeed the tax benefits that subsidize these policies are of value primarily to high bracket taxpayers. ${ }^{40}$ High-income persons are often better educated as well, and thus better able to use the comparative health care information increasingly available through these plans. ${ }^{41}$ There is evidence that participants in consumer-driven plans are making better health care decisions-using more preventive care and cutting health care costs. $^{42}$ It must be remembered, however, that these plans disproportionately cover the wealthy and well-educated, precisely those who should be able to use information to improve health care purchasing.

Between those at the bottom, covered by Mass Health or Commonwealth Care, and those at the top, covered by comprehensive insurance policies or generous HSA-linked high deductible health plans, will be a tier of those covered through the Connector without Commonwealth Care subsidies. The plans that cover these persons will likely have high deductibles and coinsurance and copayment obligations,

39. See eHealthinsurance, Health Savings ACCOUnts: January 2005-December 2005 (2006), http://www.ehealthinsurance.com/contert/ReportNew/2005HSAFullYearReport-05-10-06F. pdf, 9 (20\% of nongroup insurance plans sold by large on-line insurance broker in 2005 were sold to persons with incomes of $\$ 100,000$ or more).

40. According to one scenario, a family who invests the maximum amount in an HSA over a forty year period, paying for its medical expenses out of pocket rather than from the HSA, could accumulate $\$ 1.5$ million that could be withdrawn at retirement. Consumer Directed Health Care Inc., HSA Investment Scenario, http://www.cdhcinc.com/hsas.htm (last visited Jan. 30, 2007). If the family instead used the account to cover $\$ 1000$ in medical expenses each year and the full deductible every ten years, it would still end up with $\$ 1.25$ million. HSAs are not subject to the income limits that apply to IRAs, and are thus very attractive to high-income individuals. Even more importantly, the income placed in an HSA, unlike the income placed in an IRA, will never be taxed if it is used for qualified medical expenses-it is a tax free means to shelter income for retirement. Thomas $A$. Fogarty, Health Savings Can Be a Tax Shelter, USA TODAY, Dec. 5, 2003, at B4.

41. Existing studies tend to show that enrollees in consumer-driven health plans have higher incomes and are better educated than those who do not enroll. Melinda Beeuwkes Buntin et al., Consumer-Directed Health Care: Early Evidence About Effects on Cost and Quality, 2006 HEALTH AFF.: Web EXCLUSIVES, w516, w5 19; FRONSTIN \& COLLINS, supra note 32, at 9-10.

42. Buntin, supra note 41 , at w523-w524. However, evidence on these issues is mixed. See FRONSTIN \& COLLINS, supra note 32, at 18-33 (comparing health care decisions made by people in consumer-driven health plans with those in high-deductible health plans). 
as just noted. The premiums for these policies will be "affordable," thus the individual mandate will obligate their purchase. Failure to purchase these "affordable" policies will result in a penalty. ${ }^{43}$ But these policies may be affordable primarily because they have limited value. When a person insured through one of these policies becomes ill, the care that they will have to pay for may very well not be "affordable."

Many persons who currently have HSA-qualified high deductible health plans receive no contribution from their employers, and many lack excess money to invest in them. According to the most recent Kaiser Family Foundation survey, $37 \%$ of employers offering high deductible/HSA-eligible plans covering $30 \%$ of workers insured through such plans, do not make contributions to their employees' HSAs. ${ }^{44}$ Facing a choice between investing in an HSA or paying their next house, car, or college debt payment, the rational choice of many lower and moderate income persons in high deductible plans with an HSA option will often be to forego the small tax benefit (if any) gained from investing in the HSA in favor of meeting more immediate needs. Basically, many moderate income people with high deductible health plans have essentially catastrophic policies, their HSAs are nonexistent or largely empty. About one-fifth of HSA holders contribute nothing to their account (including over a quarter of those earning $\$ 50,000$ or less) and over one-quarter (including $35 \%$ of those with a health problem) have nothing left in the HSA at the end of the year. ${ }^{45}$ They will have to meet health care costs up to the deductible limit out of current income or borrowing, and many will face serious financial hardship if they fall seriously ill or are seriously injured.

Even the RAND Health Information Study, the holy writ of the consumer-driven health care movement, found that low-income participants suffered adverse health consequences from high costsharing. ${ }^{46}$ This has been confirmed by subsequent studies of the effects of high cost-sharing, particularly for drug purchases. ${ }^{47}$ There is also growing evidence that high cost-sharing often leads to financial disaster. The RAND study shielded participants from financial hardship, providing subsidies as well as graduated deductibles keyed to household

43. H.B. 4479, 2006 Leg., 2d Ann. Sess. $§ 13$ (Mass. 2006) (enacted).

44. KAISER FAMILY FOUNDATION, supra note 31 , at 5.

45. FRONSTIN \& COLLINS, supra note 32 , at 18.

46. NEWHOUSE, supra note 15, at 208-10, 219, 339-40 (1993).

47. John Hsu et al., Unintended Consequences of Caps on Medicare Drug Benefits, 354 NEW ENG. J. MED. 2349, 2356 (2006); Robin Tamblyn et al., Adverse Events Associated with Prescription Drug Cost-Sharing Among Poor and Elderly Persons, 285 J. AM. MED. ASs'N 421, 424-27 (2001). 
income to make sure that no one suffered financially from participating in the high cost-sharing plans. ${ }^{48}$ It did not, therefore, even examine the financial impact of cost-sharing. There is today, however, strong evidence that high cost-sharing has a devastating financial impact on those who become ill, even those who have moderate incomes and are not extremely poor.

More than one in seven American families spent $10 \%$ or more of their income ( $5 \%$ or more if low income) on out-of-pocket medical costs in 2001 and 2002, according to one study. ${ }^{49}$ Adults with health problems who have deductibles above $\$ 500$ (and particularly those with incomes below $\$ 35,000$ a year) are much more likely than those with lower deductibles to not fill a prescription, not get needed specialist care, skip a recommended test or follow-up visit, or report having a medical problem for which they have not sought medical care. ${ }^{50}$ Patients with high deductibles are also much more likely to have medical bill or medical debt problems. ${ }^{51}$ "Nearly half of underinsured adults reported that they were contacted by a collection agency" in the year prior to the survey regarding medical bills, while "more than one-third said that they had to change their way of life dramatically to pay for medical bills." 52 Medical debt is one of the most important contributors to bankruptcies in the United States. ${ }^{53}$ Therefore, for those whose incomes are immediately above $300 \%$ of the poverty level, high cost-sharing is likely to have a dramatic and deleterious effect.

It is important to remember that the goal of health care reform is not access to health insurance, it is access to health care. If a person is technically able to afford insurance, but that insurance does not make it possible for that person to afford health care, health care is not accessible. High cost-sharing makes sense for those who face a trade-off between liposuction and another new car; between an orthopedic MRI and a weekend in the Bahamas. It may be a barrier, however, to the person who has to choose between going to the doctor or dentist and

48. NEWHOUSE, supra note 15 , at $407-08$.

49. Mark Merlis et al., Rising OUt-of-Pocket Spending for Medical Care: A GRowing STRAIN ON FAMILY BudgETs, THE COMMONWEALTH FUND 3 (2006), available at http://www.cmwf.org/usr_doc/Merlis_risingoopspending_887.pdf.

50. Karen Davis eT al., how high Is too high? implications of High-Deductible Health PLANS, THE COMmONwEAlth Fund 10 (2005), available at http://www.cmwf.org/ usr_doc/816_Davis_how_high_is_too_high_impl_HDHPs.pdf.

51. Id. at 11 .

52. Cathy Schoen et al., Insured But Not Protected: How Many Adults are Underinsured? 2005 HeALTH AFF.: WEB EXCLUSIVES, w5-289,w5-296.

53. David Himmelstein et al., Illness and Injury as Contributors to Bankruptcy, 2005 HEALTH AFF.: WEB EXCLUSIVES, w5-63, w5-70. 
paying for the next meal, or even making the next payment on a rent-toown TV or used car.

Health care is not just another consumer product. The fact that Massachusetts has singled out health coverage for universal coverage, as opposed to computers or automobiles, or even food or housing, suggests that political leaders in Massachusetts believe this as well. Basic health care, like basic education, is a fundamental prerequisite to being able to accomplish anything in life. ${ }^{54}$ One can certainly argue about which health care is basic, but few of us are willing to allow someone to die in the street of an eminently treatable condition.

There are two fundamental problems that must be addressed to provide universal health care. First, there is the incredibly skewed nature of health care costs. One percent of the population in any one year is responsible for $27 \%$ of health care costs, $2 \%$ for $38 \%, 5 \%$ for $55 \%$, and $10 \%$ for almost $70 \%{ }^{55}$ Because of this, we need insurance to shift resources from the healthy to the unhealthy. Second, the distribution of wealth and income in the United States is incredibly skewed. Almost half of the population lives on $300 \%$ of the poverty level, while $1 \%$ of the population controls $40 \%$ of the nation's wealth. ${ }^{56}$ Therefore, we need government to move resources from the wealthy to the unwealthy, at least to the extent necessary to allow the unwealthy basic health care. Markets simply cannot do this.

Every other nation uses social insurance or tax-funded health services to accomplish this. ${ }^{57}$ Every system is different and does it differently and to different degrees. ${ }^{58}$ But in the end, nowhere else in the developed world do you see the level of lack of access to health care that exists in the United States.

It is quite interesting to compare the Massachusetts program to the program recently adopted by the Netherlands. ${ }^{59}$ Like Massachusetts, the

54. Thomas Rice, The Economics of Health Reconsidered, 161 (1st ed. 1998); Deborah Stone, How Market Ideology Guarantees Racial Inequality, in HEALTHY, WEALTHY, AND FAIR: HEALTh CARE AND THE GOOD SOCIETY, 65, 68 (James A. Morone \& Lawrence.R. Jacobs eds., 2005).

55. Marc L. Berk \& Alan C. Monheit, The Concentration of Health Expenditures Revisited, HEALTH AFF., Mar.-Apr. 2001, at 9, 12.

56. G. William Domhoff, Wealth, Income and Power, tbl.2, Dec., 2006, http://sociology.ucsc. edu/whorulesamerica/power/wealth.html; United States Census Bureau, Annual Demographic Survey, March Supplement, tbl.POV01, http://pubdb3.census.gov/macro/032006/pov/new 01 000.htm.

57. See Jost, supra note 3, at 433.

58. See $i d$. ("All developed nations have recognized that voluntary private insurance cannot cover everyone ... and have developed some form of public health insurance.").

59. See generally MINISTERIE VAN VOLKSGEZONDHEID, WELZIJN EN SPORT [MINISTRY OF 
Dutch system depends on an individual mandate and private insurers to provide coverage for most acute-care services. ${ }^{60}$ The Netherlands has taken four measures, however, to assure that health care is reasonably accessible to all. First, long-term care services are covered through a separate social insurance program, thus protecting the insurers from the most extraordinarily expensive form of care and making insurance more affordable. $^{61}$ Second, about half of the premiums for private health insurance are covered through income-based social insurance contributions-the more you earn the more you pay. ${ }^{62}$ Third, public subsidies are available to persons with low incomes to cover the part of the premium they would otherwise have to pay for out of pocket. ${ }^{63}$ Fourth, coverage of children is publicly financed ${ }^{64}$. In combination, these measures make health insurance affordable to most, including those with lower incomes.

Cost-sharing or user fees, as they are usually called, are in fact common throughout most of the health care systems of developed countries. $^{65}$ They usually take the form of coinsurance or copayments, though deductibles can also be found. Most countries, however, cap outof-pocket exposure at some point. Germany, for example, has copayments for drugs, ambulatory care and inpatient hospital care. ${ }^{66}$ The

Health, Welfare and SPORT], Health InSURANCE IN THE NETHERLaNDS: THE NEW HEalth INSURANCE SYSTEM FROM 2006 (2005), available at http://www.europeanvoice.com/downloads/ NL New Health Insurance System.pdf (summarizing the Dutch health care insurance system as of January 1, 2006); STEFAN GREB, MARAL MANOUGUIAN \& JÜGEN WASEM, KRANKENVERSICHERUNGSREFORM IN DEN NIEDERLANDEN: VORBILD FÜR EINEN KOMPROMISS ZWISCHEN BÜRGERVERSICHERUNG UND PAUSCHALPRÄMIE IN DEUTSCHLAND? [HEALTH INSURANCE REFORM IN THE NETHERLANDS: EXAMPLE FOR A COMPROMISE BETWEEN TAX -FINANCED AND PREMIUM-FINANCED INSURANCE IN GERMANY?] (2006), available at http://www.boeckler.de/ pdf_fof/S-2006-812-4-1.pdf (discussing the Dutch health care insurance system reform of 2006 as a possible mode for achieving reform of the German health care system).

60. MINISTERIE, supra note 59, at 4 ("Together, the entitlements existing under the Exceptional Medical Expenses Act and Health Insurance Act [requiring everyone in the Netherlands to take out insurance to cover the costs of care] offer all members of the public adequate cover against medical expenses.").

61. Id. at $\$ 3.1$, p. 28 (describing the Exceptional Medical Expenses Act, which "provide[s] for the considerable financial consequences of serious long-term sicknesses or disorders, in particular the cost of caring for disabled people with severe congenital physical or mental disorders and psychiatric patients requiring long-term nursing and care").

62. Id. at $\S 1.9$, p. 16 ("[I]ncome-related contribution[s] . . cover $50 \%$ of the total macro premium burden.").

63. Id. at $\S 2.3$, p. 24 ("Everybody with health insurance is entitled to a health care allowance ... if their premiums . . are disproportionately high compared with their income.").

64. Id. at $\S 1.9$, p. 17.

65. Ray Robinson, User Charges for Health Care, in FUNDING HEALTH CARE: OPTIONS FOR EUROPE 161, 161 (Elias Mosiallos et al., eds., 2002)

66. Reinhard Busse \& ANNETte Riesberg, Health Care Systems in Transition: GERMANY, 75 (2004). 
copayment obligation ceases, however, once a person has paid $2 \%$ of annual income for copayments, $1 \%$ if the person has a chronic illness. ${ }^{67}$ Thus, about $10 \%$ to $30 \%$ of the population has no cost-sharing obligation. $^{68}$

People who are not abjectly poor should have to pay something for health care and for health insurance. Health care is of great value, and should not be free for those who can afford it. Moreover, moral hazard is a real problem, although perhaps not as all-important as consumer-driven advocates think. Cost-sharing is a rational approach to addressing it. But no one should have to choose between health care and financial impoverishment. The Massachusetts plan does well in trying to make sure that insurance is affordable, but it may need to pay more attention to the extent to which it exposes moderate income persons with high health care costs to financial ruin. Self-insurance may be fine for the wealthy, but it can be a recipe for disaster for persons with low or moderate income. It is to be hoped that policy makers in Massachusetts will monitor implementation of their new health care plan carefully to make sure that this is not allowed to happen. Those who implement the plan should assure that deductibles, coinsurance obligations, copayments, and total out-of-pocket limits are reasonable and related to income. Only in this way can Massachusetts assure that health care is accessible and affordable to all, not just to the very poor and the very wealthy. 